Article

\title{
Impact of Climate Change Adaptation on Household Food Security in Nigeria-A Difference-in-Difference Approach
}

\author{
Oyinlola Rafiat Ogunpaimo ${ }^{1,2, *(\mathbb{D})}$, Zainab Oyetunde-Usman ${ }^{3}\left[\right.$ and Jolaosho Surajudeen ${ }^{2}$ \\ 1 Rural Economy \& Development Programme, Teagasc, Mellows Campus, Athenry, Co., \\ Galway H65 R718, Ireland \\ 2 Department of Agricultural Economics and Farm Management, Federal University of Agriculture, \\ Abeokuta 112251, Nigeria; surajudeenjolaosho@yahoo.com \\ 3 National Resources Institute, University of Greenwich, Chatham Maritime ME4 4TB, UK; \\ zainabus23@gmail.com \\ * Correspondence: oyinlolaadams@gmail.com
}

Citation: Ogunpaimo, O.R.;

Oyetunde-Usman, Z.; Surajudeen, J. Impact of Climate Change Adaptation on Household Food Security in Nigeria-A Difference-in-Difference Approach. Sustainability 2021, 13, 1444. https://doi.org/10.3390/su13031444

Academic Editor: Maurizio Tiepolo Received: 29 December 2020

Accepted: 26 January 2021

Published: 29 January 202

Publisher's Note: MDPI stays neutral with regard to jurisdictional claims in published maps and institutional affiliations.

Copyright: (c) 2021 by the authors. Licensee MDPI, Basel, Switzerland. This article is an open access article distributed under the terms and conditions of the Creative Commons Attribution (CC BY) license (https:// creativecommons.org/licenses/by/ $4.0 /)$

\begin{abstract}
Studies have shown that climate change adaptation options (CCA) are implemented to buffer the unfavorable climatic changes in Nigeria causing a decline in food security. Against the background of measuring the impact of CCA options using cross-sectional data, this study assessed how CCA had affected food security using panel data on farming households from 20102016 obtained from Nigerian General Household Survey (GHS). Data were analyzed using the Panel probit model (PPM), Propensity Score Matching (PSM), and Difference-in-Difference (DID) regression. PPM showed that the probability of adopting CCA options increased with farm size $(p<0.01)$, extension contact $(p<0.01)$, and marital status $(p<0.01)$, but decreased with the age of the household head $(p<0.01)$. Credit facilities $(p<0.05)$, ownership of farmland $(p<0.01)$, household size $(p<0.01)$, years of schooling $(p<0.01)$, household asset $(p<0.01)$, and location $(p<0.05)$ also had a significant but mixed effect on CCA choices. PSM revealed that farming households that adopted CCA strategies had 9\% higher food security levels than non-adopters. Furthermore, the result of the DID model revealed a significant positive effect of CCA on household food security ( $\beta=5.93$, $p<0.01)$. It was recommended that education and provision of quality advisory services to farmers is crucial to foster the implementation of CCA options.
\end{abstract}

Keywords: developing countries; welfare; panel probit model; adoption; propensity score matching

\section{Introduction}

The agricultural practices in African nations especially Nigeria largely rely on the natural weather conditions of the locality. Changes in the climatic condition of the country are evident in increased desert encroachment and extreme droughts in the Northern region $[1,2]$, likewise the problem of persistent flood and erosion occurrence in the Southern region. Climatic variability and changes have been linked to erosion, increased flooding, environmental degradation [3], and a decrease in agricultural productivity [4,5].

Frequent and intense weather events as a result of climate change are likely to impact the welfare and food security status of both the rural and urban populace through poor food production, poor land availability, and reduced opportunities [6]. The optimal usage of land for crop and animal production, biodiversity restoration, health, and well-being can also be negatively impacted by increased temperature and precipitation changes, and increased weather fluctuations [7-9].

In accordance with the 2020 global food security index, Nigeria's food insecurity status is considered serious in the severity chart [10]. The Federal Ministry of Agriculture of Nigeria in 2014 estimated that $65 \%$ of the population is food insecure despite having more than half of all employments dependent on agriculture [5]. Among several other factors, heightened food insecurity among farm households is caused by limited access to 
credit, poor storage and improved agricultural facilities, and negative environmental influences such as erosions and floods [5]. Other reasons include the lower household income necessary for food purchases needed to attain food security [11], increased population growth [12,13], and a huge reliance on imported food items [14]. The 2030 United Nations Sustainable Development Goals are new global policies with the objective to restructure regional and national development plans over the next 10 years. The global policy aims to put an end to poverty and hunger, food insecurity, sustaining natural resources and the environment, and promote food and agriculture sustainability [15].

The International Symposium on Climate and Food Security (ISCFS) and Intergovernmental Panel on Climate Change (IPCC) Fourth Assessment Report (AR4) also recognized three critical global problems of poverty and hunger, increased population growth, and unfavorable weather and climate [16]. Agricultural production and climate change exhibit a feedback relationship, while agricultural activities may result in increased emissions and pollutions leading to climatic changes, climate change also influences agricultural output. Research has indicated that by 2030, the negative consequence of climate change on agriculture will be more severe across all the countries of the world [17]. Climatic changes already have an antagonistic influence on food security with the number of chronically undernourished people in the world estimated to have increased by 38 million in 2016, in addition to 777 million recorded in 2015 [18], thus, without proper implementation of adaptation and mitigation measures, climate variability and change will threaten the achievements of the SDG goals in eradicating poverty and hunger [17].

As stated by the United Nations Framework Convention on Climate Change (UNFCCC, 2007) AR4 and buttressed by Field [19] and Steynor and Pasquini [20], Africa is predicted to be the continent most susceptible to climate change and variability; adverse climatic impacts are worsening the livelihoods, welfare, and regional and household food security in tropical developing regions [17]. Consensus exists that climate change and variability will have a significantly negative impact on all these aspects of food security in Africa [21]. Like other African countries, studies such as Ebele and Emodi [22] reported that the projected impact of climate change on West Africa's agricultural productivity could lead to a $4 \%$ reduction in the region's GDP; in Nigeria, the adverse influence of climate change on food security is evidenced by the changes in plant duration and output of cereal crops, reductions in aquatic life [23], and livestock failure [24]. In tackling climate change and variability, studies $[25,26]$ indicate that CCA can promote household food security. While research had been conducted on factors influencing the choice of CCA by farming households and the impact of CCA options on household food security, very few studies if any had applied a panel data analysis approach to investigate the influence of CCA options on household food security in Nigeria.

Morland [27] stated that small scale farmers in Africa experience weather variability and other climate-change-related events. Among farm households, varieties of climateadaptation methods abound and this includes diversification and crop rotation, engaging in non-agricultural income-generating activities, practicing soil and water conservation techniques, adjusting the times they sow their lots, use of irrigation and creation of flood barriers, adopting improved seed varieties and fertilizers, tree-planting, and integrating crop production with livestock.

Adaptation to climate change and variability means anticipating the adverse effects of climate variability and taking appropriate action to prevent and or minimise the damage they cause or taking advantage of opportunities that may arise [28]. It involves the use of climate sustainable practices to reduce the negative consequences of climate change.

In many African countries, especially Nigeria, access to food will be severely affected by climate change. Africa is the region where climate change and variability have had the biggest impact on acute food insecurity and malnutrition, affecting 59 million people in 24 countries [7]. Given these discouraging prospects, it is no surprise that the adaptation strategies are vital to support the climate effects on food security. These strategies can indeed buffer against climate variability and play a crucial role in promoting the food 
security of farm households, thereby reducing the negative effect of climate variability on food security.

Thus, this research sought to investigate the impact of climate change adaptation on farm households' food security status by providing answers to the following questions: (1) What are the factors affecting climate adaptation strategies employed by farm households in Nigeria? (2) What is the impact of climate change adaptation on household food security?

\section{Materials and Methods}

This section describes the study area, the data source, a summary of farm household characteristics, the description of variables, and the method of data analysis.

\subsection{Study Area}

The study area is Nigeria situated $4^{\circ}$ and $14^{\circ} \mathrm{N}$, and longitudes $2^{\circ}$ and $15^{\circ}$ E. Nigeria is located in West Africa with its capital at Abuja created in 1976 having a total area of $923,769 \mathrm{~km}^{2}$ (356,669 sq mi) [29], making it the world's 32nd largest country. Nigeria is bordered to the north by Niger, to the east by Chad and Cameroon, to the south by the Gulf of Guinea of the Atlantic Ocean, and the west by Benin [29].

Like most countries in sub-Saharan Africa, the climatic condition in Nigeria is tropical with varying rainy and dry seasons. The Nigeria vegetation belts, also known as the agroecological zones range from the mangrove, freshwater swamps, and tropical rainforest which extends from the South-South, South-East to South-West regions. The tropical savanna grasslands zone is dominant in the middle belts with Sudan and Sahel Savanna in the Northern regions. Agricultural production is dominant in the northern agroecological zones, however, climatic changes and human activities such as continuous cropping, overgrazing, and bush burning especially in densely populated areas have highly impacted the agricultural vegetation.

Specifically, in the far northern areas, the nearly total disappearance of plant life has facilitated a gradual southward advance of the Sahara [29]. The map of Nigeria showing the different regions and states is illustrated as shown in Figure 1.

\subsection{Data Source}

Panel data on relevant socioeconomic, demographic, consumption, and production data of farming households from 2010-2016 were obtained from the World Bank and the Nigeria Bureau of Statistics (NBS) General Household Survey (GHS). The GHS is a nationally representative survey with respondents obtained from the 36 states of Nigeria including the Federal Capital Territory. Three waves of the Living Standard Measurement Survey (First wave-2010/2011 Ref. NGA_2010_GHSP-W1_v03_M [30], Second wave2012/2012 Ref. NGA_2012_GHSP-W2_v02_M [31] and the Third-wave-2015/2016 Ref. NGA_2015_GHSP-W3_v02_M [32]) was employed such that there are six-period panel data for the farm households from which 3500 farm households were used for this study.

\subsection{Summary of Characteristics of Farm Households in the Study Area}

The summary of farm households' characteristics is shown in Table 1. Age is an important determinant of farm activities. It is believed that younger people commit more energy to production activities, while older farmers are likely to be more experienced. The mean age of respondents was 50.4 and 53.2 years in 2010 and 2016 respectively. In relation to the gender of the household head, the majority of family households were male-headed. Male household heads accounted for $88.36 \%$ in 2010 to a slight reduction of $84.14 \%$ in 2016 . This report buttresses the dominance of males in farming activities in Nigeria as reported by [33]. However, the decline in the proportion of male-headed households in the study area may be due to increasing awareness of female empowerment and capacity building in the area. 
Table 1. Summary of Farm Households' Characteristics in the Study Area.

\begin{tabular}{|c|c|c|c|c|c|}
\hline \multirow{3}{*}{ Characteristics } & & \multicolumn{4}{|c|}{ Year } \\
\hline & & \multicolumn{2}{|c|}{2010} & \multicolumn{2}{|c|}{2016} \\
\hline & & Percentage & Mean & Percentage & Mean \\
\hline \multirow{2}{*}{ Gender of $\mathbf{H H}$} & Female & 11.64 & & 15.86 & \\
\hline & Male & 88.36 & & 84.14 & \\
\hline \multirow{2}{*}{ Marital status } & Single & 15.00 & & 20.43 & \\
\hline & Married & 85.00 & & 79.57 & \\
\hline \multirow{2}{*}{ Accessed credit } & Yes & 2.94 & - & 24.01 & \\
\hline & No & 97.06 & & 75.99 & \\
\hline \multirow{2}{*}{ Extension contact } & Yes & 14.38 & & 86.79 & \\
\hline & No & 85.62 & & 13.21 & \\
\hline \multirow{2}{*}{ Ownership of land } & Yes & 29.07 & & 1.24 & \\
\hline & No & 70.93 & & 98.76 & \\
\hline Age of $\mathbf{H H}$ & & & 50.4 & & 53.2 \\
\hline HH SIZE & & & 6 & & 8 \\
\hline Years of schooling & & & 6 & & 7 \\
\hline Household asset & & & 11 & & 41 \\
\hline Plot size & & & $11,372.38$ & & 10,264 \\
\hline Secondary income & & & $13,465.25$ & & 5672.59 \\
\hline Total food expenditure & & & $16,382.38$ & & $21,867.58$ \\
\hline Total non-food expenditure & & & 7137.23 & & 8350.23 \\
\hline Total expenditure & & & $23,519.61$ & & $30,217.83$ \\
\hline
\end{tabular}

Author's Computation from LSMS Data 2010:2016.

As illustrated in Table 1, the majority (85\%) of farming households in 2010 were married, this came down to $79.57 \%$ in 2016 . In terms of educational level, the average years of schooling were 6 years with no significant change in 2016 implying that although farm households have access to formal education, the level of education among farming households in Nigeria is still low. However, by 2016 the average years of schooling had increased by a year in the country due to various campaigns and probable enlightenment on the need for female education in the region. Following apriori expectation education is likely to increase the probability of farming households adapting to climate changes because it can be assumed that education will increase farm household's awareness of CCA.

The size of households is also shown in Table 1. It is evident that the average household size for the sampled farm households' was approximately six persons in 2010 to eight persons in 2016. Previous literature [35-37] argued that the probability of adopting labourintensive adaptation measures increases with family size due to the availability of free or inexpensive man-power. Also, large families divert part of their labour force into non-farm activities to generate more income [38,39].

From Table 1, the majority of respondents $(85.62 \%)$ had no access to extension contact in 2010, however, in 2016 the majority (86.79\%) had access to extension contact. This showed the intensification of extension services contact increased over the years within the study area. For access to formal credit, the majority (97.5\%) of the respondents did not have access; this may limit the ability of the farmers to expand their scale of production. This result is buttressed by the findings of [40] who assessed the trend of formal credit allocation to food crop production in Nigeria; their results showed that there was a decreasing trend in the credit allocation to the food crop production since 2011. It can be argued that agriculture production is constrained in Nigeria by poor credit delivery; the delivery of credit facilities in the country is largely in favour of the wealthy farmers as opposed to poor farmers; the wealthy farmers may utilize the loan acquired for ulterior motives rather than the initial function of agricultural production [40,41]. This limited access to credit facilities may be as a result of high-interest rates credit facilities provided by financial institutions among other bureaucratic delays inherent in loan assessment, acquisition, and disbursement in Nigeria. 
Ownership of land can serve as an indicator of the wealth status of farming households [25], and thus it can be expected that the increased wealth status of farming households leads to increased food security of farm households. The distribution of the ownership of land is illustrated in Table 1; the result obtained showed that the majority (98.76\%) of farm-households owned land compared to 2010 where the majority $(69.96 \%)$ of farm households had no access to land.

The summary of average food expenditures and, by extension, food security of farm households, is presented in Table 1. A household is categorized to be very vulnerable to food insecurity if more than $75 \%$ of its total expenditure is spent on food items whereas people spending $65-75 \%$ are considered to have high food insecurity [11,42]. Following Engel's law, the higher the food expenditure share, the lower the food security of farm households. Thus, the food security status of farm households measured as household food expenditure share slightly reduced in 2016 with average farm households spending approximately $72 \%$ of their expenditure on food compared to 2010 when an average farm household spent about $69.6 \%$ of their expenditures on food.

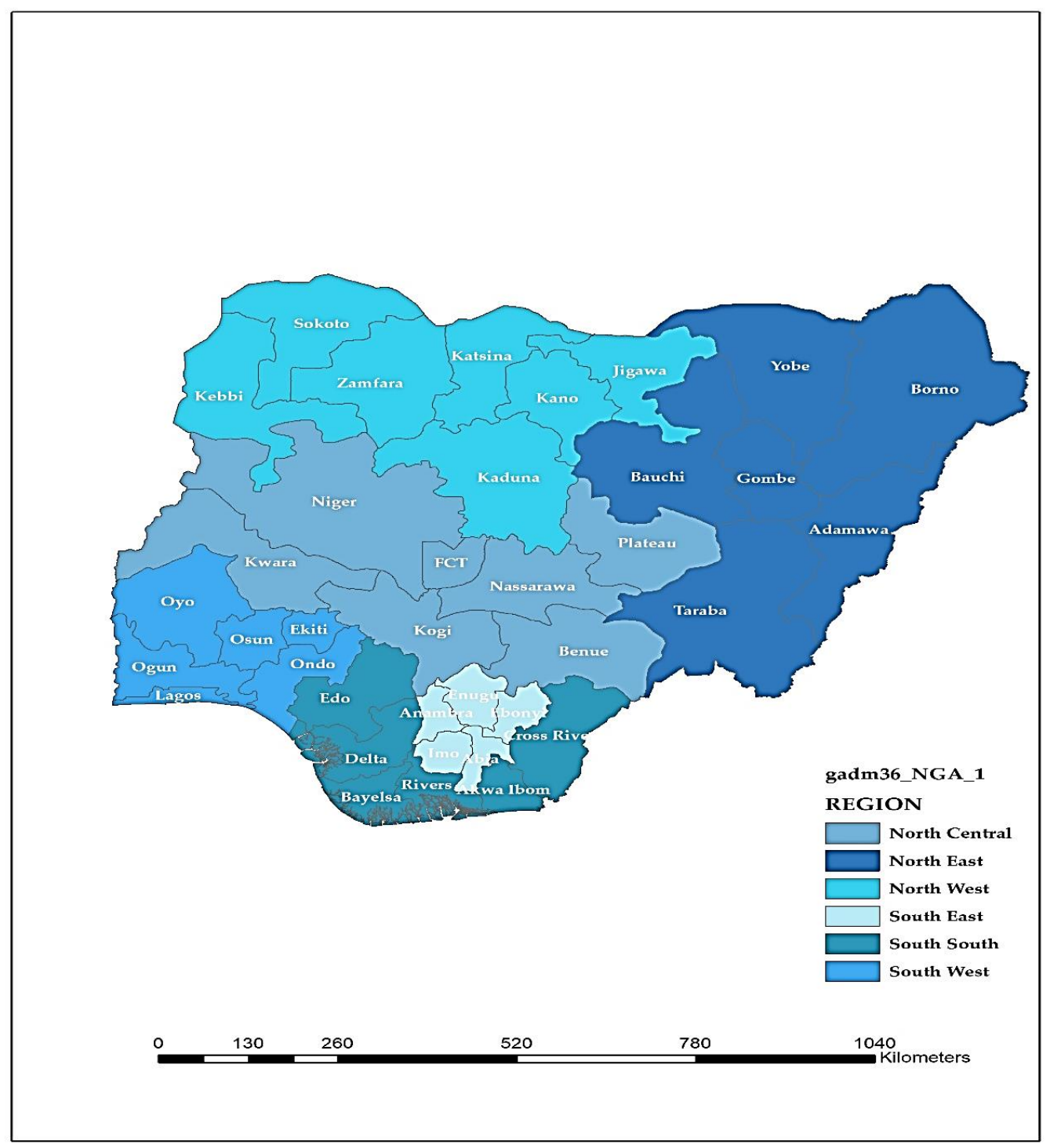

Figure 1. Geographical subdivisions of Nigeria showing the 36 states, Federal Capital Territory, and the six geo-political regions of the country obtained by computation of GADM [34] geo package Data. 


\subsection{Analytical Techniques}

The method of data analysis adopted in this study to achieve the stated objectives includes:

\subsubsection{Panel Probit Model}

The pooled probit model specification of the panel data model was employed to evaluate the factors affecting CCA strategies employed by farm households for this study [43,44]. Following Akerele et al. [43], the panel probit model is expressed as follows:

$$
y_{j i t}^{*}=a+X_{j t} \beta+e_{j i t}
$$

where

$y_{j i t}^{*}=$ the latent (underlying) variable that determines whether farm household $j$ would be classified as an adopter of CCA measure $i$ at time $t$;

$\beta=$ a vector coefficient;

$X_{j t}=$ a matrix of explanatory variables;

$a=$ the constant term; and

$e_{j i t}=$ the idiosyncratic errors assumed to have zero mean and unit variance. The relationship between the latent variable $y_{j i t}^{*}$ and the observed outcome $y_{j i t}$ is represented as

$$
y_{j i t}=\left\{\begin{array}{l}
0 \text { if } y_{j i t}^{*}<0 \\
j \text { if } y_{j i t}^{*}>0
\end{array} \quad \text { for } i=1, \ldots \ldots \ldots, n \quad \text { and } j=1, \ldots . p-1\right.
$$

where $y_{j i t}=1$ if a farm household adopts a CCA strategy for each adaptation strategy.

The selection of the variables was motivated by previous literature [4,25,45-47], availability of data [48], and economic theories [4] on factors influencing the choice of CCA and are presented in Table 2. Farm and household attributes were included as explanatory variables for assessing determinants of CCA options. Ownership of land or tenancy status was used as a determinant mainly because these can act as proxies for the wealth status of the farm households [25].

Table 2. The Description Measurement and A Priori Expectation of the Variables.

\begin{tabular}{cccc}
\hline Variable & Description & Measurement & A Priori Expectation \\
\hline X1 & Age of household head & Years & \pm \\
X2 & Accessed credit & Dummy: 1 for yes; 0 no & + \\
X3 & Tenancy status & Dummy: 1 for farm owner; 0 otherwise & + \\
X4 & Farm size & Hectares & + \\
X5 & Accessed extension contact & Dummy: 1 for yes; 0 no & + \\
X6 & Household size & Dummy: 1 for male; 0 otherwise & + \\
X7 & Gender of the HH & Dummy: 1 for married; 0 otherwise & + \\
X8 & Marital status & Years & + \\
X9 & Educational level of HH & Naira & + \\
X10 & Secondary occupation income & Number & + \\
X11 & Quantity of household asset & Dummy: 1 for yes; 0 otherwise & + \\
X12 & North Central & Dummy: 1 for yes; 0 otherwise & + \\
X13 & North East & Dummy: 1 for yes; 0 otherwise & + \\
X14 & North West & Dummy: 1 for yes; 0 otherwise & + \\
X15 & South East & Dummy: 1 for yes; 0 otherwise & + \\
X16 & South West & & + \\
\hline
\end{tabular}

Following Teklewold et al. [4], socio-demographic characteristics of farm households important in implementing CCA options were controlled for, these factors include age, gender, household size, gender, and educational level of the household head. Resource constraint was also considered while accounting for the factors influencing CCA options. Quantity of household assets can act as a proxy in measuring the wealth status of farm households [4]; access to credit facilities extension services was included as one of the 
explanatory factors since extension services provide crucial education and information needed to adopt CCA options $[25,46]$.

Following from this, the four categories of adaptation strategies were considered in this study, these measures were selected based on the popularity of these measures amongst farm households across all the geo-political zones in Nigeria considered in this study:

Diversify more into other crops

Used Irrigation facilities

Diversify into off-farm activities

Implement soil conservation techniques

Adoption of crop diversification is a CCA method that may involve the planting of high yield variety and drought-resistant crops or intercropping [48], which has been extensively identified from previous studies as an option that can help farmers and farming households buffer the negative effects of climate change. Planting of crops such as cereals that are highly affected with sporadic fluctuations in weather patterns along with turgid crops such as cassava will minimize crop losses due to weather events $[33,49]$.

Implementation of soil conservation techniques such as fallowing and practicing alley cropping can aid in the restoration of soil nutrients, minimize nutrient loss, protects the vegetation cover, and also reduces organic matter oxidation in the soil [49]. Alley cropping can aid in reducing soil erosion while also serving as windbreaks.

Water as a resource is crucial for optimal crops and livestock cultivations [48]. Several studies such as [48-51] documented the importance of implementation of irrigation facilities especially in regions prone to drought or low rainfall occurrences. The adoption of irrigation is encouraged to augment the rainfall amount required for optimal crop cultivation.

Off-farm diversification has been extensively used as a CCA strategy as evidenced by previous literature [51,52]. Farming households may undergo off-farm activities or other occupation during the dry season, unfavourable climate conditions [51] or mainly to complement income sources in order to meet household food security status.

Estimating the impact of climate change adaptation on household food security in Nigeria was achieved in two stages using a combination of two analytical tools, which were described as 2.4.2 (Propensity Score Matching) and 2.4.3 (Difference-In-Difference).

\subsubsection{Propensity Score Matching}

This study employed PSM to estimate the impact of the adaptation strategies on farm household food security status. The PSM is defined as the conditional probability that a farm household adopts the new adaptation strategies, given pre-adoption characteristics [53]. To mimic a typical randomized controlled experiment, the PSM assumes the unconfoundedness assumption, also known as conditional independence assumption, which implies that once $\mathrm{Z}$ is controlled for, technology adoption is random and uncorrelated with the outcome variables. The PSM also accounts for this sample selection bias $[25,54]$.

Following the framework of Ali and Erenstein [25], the PSM was used to estimate the impact of climate change adaptation on farm households' food security. After investigating the choice determinants of CCA practices using PPM, a propensity score matching approach was employed to analyse the impact of adaptation practices on food security.

The farm households were classified as food secure or food insecure based on their share of total household expenditure spent on food. Following Ali and Erenstein [25,42], Smith, et al. [55], households spending more than $75 \%$ of their expenditures on food were categorized as food insecure households and were assigned a dummy value of zero; while farm households were categorized as food secure and assigned a value of 1 when the food expenditure is below the threshold level ( $75 \%)$ of total expenditure. 
A risk-averse farm $F_{i}$ opts for a few strategies $\left(S_{j}\right)$. It is assumed that households that have opted for adaptation strategies have higher utility levels compared to those that have not: [25].

$$
U\left[F\left(S_{1}\right)\right]>U\left[F\left(S_{0}\right)\right]
$$

The PSM can be expressed as according to Ali and Erenstein [25]:

$$
\mathrm{P}(\mathrm{Z})=\operatorname{Pr}\{I=1 \mid Z\}=E\{1 \mid Z\}
$$

where $I=$ is the indicator for adoption and

$Z=$ the vector of pre-adoption characteristics.

The conditional distribution of $Z$, given $p(Z)$, is similar in both groups of adopters and non-adopters.

The expected treatment effect for the treated population is of primary significance and is given as

$$
\tau_{\left.\right|_{i=1}}=E(\tau \mid I=1)=E\left(R_{1} \mid I=1\right)-E\left(R_{0} \mid I=1\right)
$$

where $\tau=$ the average treatment effect for the treated (ATT),

$R_{1}=$ denotes the value of the outcome for adopters of the adaptation, and

$R_{0}$ is the value of the same variable for non-adopters.

As noted above, the major problem is that we do not observe $E\left(R_{0} \mid I=1\right)$, in other words, it is potentially a biased estimator.

After estimating the propensity scores, the average treatment effect for the treated (ATT) can then be estimated as $[25,56]$

$$
\begin{aligned}
\tau & =E\left(R_{1}-R_{0} \mid I=1\right)=E\left\{E\left\{R_{1}-R_{0} \mid I=1, p(Z)\right\}\right\} \\
& =E\left\{E\left\{R_{1} \mid I=1, p(Z)\right\}-E\left\{R_{0} \mid I=0, p(Z)\right\}\right\}
\end{aligned}
$$

PSM is based on two underlying assumptions, that is: the common support and the conditional independence assumption [25]. A diagnostic test of matching quality must be carried out after matching to estimate the standard errors and treatment effects. Some balancing tests were to be carried out to access the matching quality, mean absolute bias, $\mathrm{t}$-statics, and the bias reduction before and after matching $[57,58]$.

\subsubsection{Difference-in-Difference}

DID was also used to assess the impact of CCA on household food security; unlike the PSM which estimates the impact of CCA on household food security between adopters of CCA and non-adopters, DID evaluates the impact of CCA over time, that is from 2010 to 2016.

Difference-in-difference (DID) methods, compared with PSM, assume that unobserved heterogeneity in adoption is present but that such factors are time-invariant. With data on project and control observations before and after the CCA adoption, therefore, this fixed component can be differenced out. Some variants of the DID approach have been introduced to account for potential sources of selection bias. Combining PSM with DID methods can help resolve the problem of selection bias, by matching units in the common support [56]. The propensity score can be used to match participant/adopters and control/non-adopters units in the base year, and the CCA impact is calculated across adopters and matched control units within the common support. For two time periods $t=\{1,2\}$, the DID estimate for each adoption area $i$ will be calculated as

$$
D I D_{i}=\left(Y_{i 2}^{T}-Y_{i 1}^{T}\right)-\sum_{j \in C} \omega(i, j)\left(Y_{i 2}^{C}-Y_{i 1}^{C}\right)
$$

where

$\omega(i, j)$ is the weight (using a PSM approach) given to the $j$ th control area matched to adoption area $i$. 
$Y_{i 2}^{T}=$ Farm household food security status of CCA adopters in 2016.

$Y_{i 1}^{T}=$ Farm household food security status of CCA adopters in 2010

$Y_{i 2}^{C}=$ Farm household food security status of non-adopters of CCA in 2016

$Y_{i 1}^{C}=$ Farm Household food security status of non-adopters of CCA in 2010.

\section{Results and Discussion}

The findings of this research work, interpretations, and also discussion of the result are presented in this section.

\subsection{Determinants of Farm Households Climate Change Adaptation Options}

A panel probit model was used in this study to estimate the factors affecting adaptation strategies employed by farming households. Adaptation options identified include

Irrigation

Soil conservation

Crop diversification

Diversification into non-farm activities

The likelihood ratio test from the Panel probit model showed the overall significance of the models at $(p<0.01)$ probability level, which signified that the model is useful in explaining factors influencing decisions of farming households to adapt to climate change.

Age of Household Head: As shown in Table 3, the age of the household head is an important determinant in the decision of farming households to use irrigation $(p<0.01)$, and diversify into non-farm activities $(p<0.01)$. The sign of the parameter is negative, implying that the older the household head, the less likely their probability to adopt irrigation and diversify into non-farm activities. It can be deduced from the result that with a year increase in the age of farmers the probability of implementing irrigation facilities and practicing non-farm diversification decreases by $1 \%$ and $0.4 \%$ respectively. These findings suggest that younger farmers are more likely to adopt these CCA strategies compared to their older counterparts, possibly because they are innovative and keen to try new technology and methods to improve agriculture, whereas older farmers through years of experience may understand the negative economic implications of practicing such strategies. These findings are in support of Ali and Erenstein [25]; where the age of the household head had a negative relationship with CCA adoption, they claimed that older farmers may be conservative about trying new and innovative agricultural practices despite increased awareness. However, the result was against the findings of [59-61] who found that age had a positive association with CCA adoption among farming households.

Access to Credit Facilities: Access to credit facilities was positively significant $(p<0.01)$ for practicing soil conservation and off-farm diversification (shown in Table 3), which is in support of Hassan and Nhemachena [62] and Ojo and Baiyegunhi [63]. In their study, they opined variations to farmers' adaptation options, which are largely dependent on their access to credit and information on credit. On the other hand, access to credit facilities has a negative but significant $(p<0.10)$ effect on the probability of using irrigation facilities. This may be due to the cost implication attached to the use of irrigation and the predictive risk of being unable to refund the credit owed when due. The effect on irrigation facilities is in line with [59] but opposed to findings in [64]. Hisali et al. [59] reported that households without credit have a greater likelihood of implementing CCA options, the suggested situations like this may occur where repayment of credit leads to resource constraint needed for CCA adoption or that credit can be used for other purposes other than climate change adaptation. 
Table 3. Parameter Estimates of Panel Probit Model of Determinants of Farming Households CCA Strategies.

\begin{tabular}{|c|c|c|c|c|}
\hline & Irrigation & $\begin{array}{c}\text { Soil } \\
\text { Conservation }\end{array}$ & $\begin{array}{c}\text { Crop } \\
\text { Diversification }\end{array}$ & $\begin{array}{c}\text { Diversify into } \\
\text { Other Occupation }\end{array}$ \\
\hline Credit & $\begin{array}{l}-0.14 * \\
(-1.82)\end{array}$ & $\begin{array}{c}0.13 * * * \\
(2.61)\end{array}$ & $\begin{array}{c}-0.20 \\
(-0.38)\end{array}$ & $\begin{array}{c}0.23 * * * \\
(5.30)\end{array}$ \\
\hline Tenancy Status & $\begin{array}{c}0.05 \\
(1.19)\end{array}$ & $\begin{array}{l}0.10 * * * \\
(39.49)\end{array}$ & $\begin{array}{l}0.26 * * * \\
(7.97)\end{array}$ & $\begin{array}{l}-0.08^{* * *} \\
(-2.99)\end{array}$ \\
\hline Farm size & $\begin{array}{c}0.02 * * * \\
(3.55)\end{array}$ & $\begin{array}{l}0.03 * \\
(1.86)\end{array}$ & $\begin{array}{c}0.03^{* * *} \\
(4.10)\end{array}$ & $\begin{array}{c}0.08 \\
(1.62)\end{array}$ \\
\hline Extension contact & $\begin{array}{l}0.17^{* * *} \\
(2.89)\end{array}$ & $\begin{array}{l}-0.09 * \\
(-1.61)\end{array}$ & $\begin{array}{l}0.24^{* * *} \\
(4.07)\end{array}$ & $\begin{array}{c}-0.07 \\
(-1.64)\end{array}$ \\
\hline Household size & $\begin{array}{l}0.02 * \\
(1.90)\end{array}$ & $\begin{array}{c}0.06^{* * *} \\
(9.17)\end{array}$ & $\begin{array}{c}0.01 \\
(0.68)\end{array}$ & $\begin{array}{c}0.04^{* * *} \\
(6.27)\end{array}$ \\
\hline Age of $\mathrm{HH}$ & $\begin{array}{l}-0.01 * * * \\
(-3.03)\end{array}$ & $\begin{array}{c}0.01 \\
(0.69)\end{array}$ & $\begin{array}{l}-0.01 \\
(-0.11)\end{array}$ & $\begin{array}{c}-0.004^{* * *} \\
(-4.74)\end{array}$ \\
\hline Gender of $\mathbf{H H}$ & $\begin{array}{l}-0.07 \\
(-0.75)\end{array}$ & $\begin{array}{c}0.30 * * * \\
(4.69)\end{array}$ & $\begin{array}{l}-0.02 \\
(-0.38)\end{array}$ & $\begin{array}{l}-0.11^{* *} \\
(-2.38)\end{array}$ \\
\hline Marital status & $\begin{array}{l}0.24 * * \\
(2.19)\end{array}$ & $\begin{array}{l}-0.16^{* *} \\
(-2.55)\end{array}$ & $\begin{array}{c}0.28 * * * \\
(5.17)\end{array}$ & $\begin{array}{c}0.26^{* * *} \\
(5.13)\end{array}$ \\
\hline Years of schooling & $\begin{array}{l}-0.01 \\
(-0.04)\end{array}$ & $\begin{array}{l}-0.04^{* * *} \\
(-12.35)\end{array}$ & $\begin{array}{l}-0.02 * * * \\
(-6.29)\end{array}$ & $\begin{array}{c}0.02 * * * \\
(7.27)\end{array}$ \\
\hline HH asset & $\begin{array}{l}-0.01^{* * *} \\
(-3.16)\end{array}$ & $\begin{array}{l}-0.09 * * * \\
(-15.66)\end{array}$ & $\begin{array}{l}-0.01 * * * \\
(-7.12)\end{array}$ & $\begin{array}{l}0.003^{* * *} \\
(3.79)\end{array}$ \\
\hline North Central & $\begin{array}{l}0.35^{* *} \\
(2.23)\end{array}$ & $\begin{array}{c}0.49 * * * \\
(7.65)\end{array}$ & $\begin{array}{l}0.28 * * * \\
(3.80)\end{array}$ & $\begin{array}{l}-0.54^{* * *} \\
(-7.51)\end{array}$ \\
\hline North East & $\begin{array}{c}-0.03 \\
(-0.17)\end{array}$ & $\begin{array}{c}0.56^{* * *} \\
(8.68)\end{array}$ & $\begin{array}{l}0.15^{* *} \\
(2.10)\end{array}$ & $\begin{array}{l}-0.42^{* * *} \\
(-5.88)\end{array}$ \\
\hline North West & $\begin{array}{c}0.56^{* * *} \\
(3.71)\end{array}$ & $\begin{array}{c}0.48^{* * *} \\
(7.37)\end{array}$ & $\begin{array}{l}1.12 * * * \\
(12.35)\end{array}$ & $\begin{array}{c}-0.18^{* * *} \\
(-2.52)\end{array}$ \\
\hline South East & $\begin{array}{l}-0.01 \\
(-0.04)\end{array}$ & $\begin{array}{c}0.55^{* * *} \\
(8.48)\end{array}$ & $\begin{array}{l}1.43^{* * *} \\
(15.11)\end{array}$ & $\begin{array}{c}-0.25^{* * *} \\
(-3.52)\end{array}$ \\
\hline South West & $\begin{array}{l}-0.35 \\
(-1.62)\end{array}$ & $\begin{array}{c}0.50 * * * \\
(6.38)\end{array}$ & $\begin{array}{c}0.06 \\
(0.99)\end{array}$ & $\begin{array}{c}0.47^{* * *} \\
(5.37)\end{array}$ \\
\hline Constant & $\begin{array}{l}-2.12 \\
(-9.79)\end{array}$ & $\begin{array}{c}-1.99 \\
(-19.02)\end{array}$ & $\begin{array}{c}0.38 \\
(3.50)\end{array}$ & $\begin{array}{c}-0.16 \\
(-1.70)\end{array}$ \\
\hline Number of Observations & 18,873 & 18,873 & 18,873 & 18,873 \\
\hline Log-Likelihood & $-0.07 * * *$ & $-4262.18^{* * *}$ & $-6173.30^{* * *}$ & $-9332.21 * * *$ \\
\hline Wald Chi2(14) & $0.21 * * *$ & $2371.78 * * *$ & $745.85 * * *$ & $431.58 * * *$ \\
\hline$p$-Value & $-0.05 * *$ & $0.000 * * *$ & $0.000 * * *$ & $0.000 * * *$ \\
\hline
\end{tabular}

${ }^{* * *}$ and ${ }^{* * *}$ represents statistical significance at $10 \%, 5 \%$ and $1 \%$ respectively. Authors computation of LSMS data 2010-2016.

Tenancy Status: The influence of ownership of farmland is reported in Table 3. As indicated ownership of farmland has a mixed effect on adaptation options, it has a direct and significant relationship with soil conservation $(p<0.01)$ and crop diversification $(p<0.01)$. With ownership of land, the decision on the usage of land rests solely on the farmer, due to the availability of lands, it is easier for the farmer to leave some portion of his land for fallowing and also utilize the farm for the cultivation of crops with varying lifecycles since he does not have to fear he may lose his tenancy status. The cost of incurring land is null, therefore, there are more funds available to go into planting various crops. Quan [65] and Kokoye, et al. [66] concluded that land ownership availability can be an incentive for farmers to invest in resources for farming because farmers can pass their land on to the next generation; therefore, they are more willing to care for the land by adopting practices that can aid to maintain its productivity and food security in the context of climate change. Conversely, ownership of farmland has a negative and significant relationship in practicing alley cropping and diversifying into non-farm activities. The relationship between ownership of farmland and diversifying into nonfarm activities is expected because farmers may have invested so much in their farming business; another reason is that owning land may increase the profitability of the business. Previous studies, however, showed mixed results for the relationship between tenancy status and adoption of CCA options. While some studies $[67,68]$ posit a direct relationship between land ownership and adoption of CCA options, other studies such as [25,69-73] reported a negative correlation. The latter are 
variously associated with the need for farmers in this category to have more agriculturally reliant livelihoods.

Farm size: Farm size has a significant influence on CCA options. An increase in farm size increases the probability of farmers adopting irrigation $(p<0.01)$, implementing soil conservation techniques $(p<0.01)$, and practicing crop diversification. From Table 3 , a 1 hectare increase in farm size increases the likelihood of farm households implementing irrigation, soil conservation techniques, and crop diversification by $2 \%, 3 \%$, and $3 \%$ respectively. Findings are in support of several studies that generally reported a positive association between CCA adoption and farm size [25,70,74,75]. Farmers with large land possessions are likely to have more capacity to try out and invest in climate risk-coping strategies. As reported by Arunrat et al. [64], an increase in farm size and land ownership reduces bureaucratic delays with regards to decisions about CCA adoption, mainly because of their ability to procure the high capital and landholdings, and the freedom required to implement innovative practices on their land.

Extension Contact: Studies such as Adams [39], Tambo [51], Boansi, Tambo and Müller [61], and Gbetibouo [76] have shown significant effects of access to extension contact on adopting CCA options. The result of the PPM confirmed that access to the extension has a positive and significant $(p<0.01)$ impact on irrigation use and crop diversification; from Table 3, it can be inferred that a unit increase in farm households' access to extension contact increases the likelihood of implementing irrigation and crop diversification by $17 \%$ and $24 \%$ respectively. The reason behind it is that extension services help disseminate innovations likely denoting the role of advisory services, and access to information among other resources may motivate the farm household to implement such CCA strategies [70,71]. These findings support those of Tambo [51], Boansi, Tambo and Müller [61], and Gbetibouo [76], which showed that extension services enhanced the availability of information on CCA options.

Household Size: It is positive and significant $(p<0.01)$ for the probability of households to diversify into non-farm activities and implement soil conservation techniques. Increasing household size results in an increase in food expenditure and the compulsion to meet this need comes from non-agricultural income sources. Ali and Erenstein [25], Deressa, Hassan and Ringler [45], and Arshad, et al. [77] revealed similar results of the increase in household size, which increases the probability of adopting a strategy. This is likely due to the prevalence of family labour, which makes task achievement more effective, especially during peak periods. Adams [39], Temesgen, Hassan, Tekie, Mahmud and Ringler [47], and Le Dang, et al. [78] contradict the positive influence of household size; they opined that household size has a negative and significant impact on the probability of choosing adaptation strategies.

Gender of Household Head: Results obtained in Table 3 are partially in tandem with previous findings $[46,50,79,80]$ that male-headed households often have a higher likelihood of adopting agricultural innovations and thus are better adapted to climate change. Being a male-headed household increases the chances of practicing soil conservation compared to their female counterparts. However, the likelihood to diversify into other occupations increases with being a female-headed household because females in the household especially in Nigeria are found to play supportive roles (such as processors and traders) in the households by diversifying the household income, thus easing the financial burden of the family. Females in households also tend to make financial plans for unforeseen circumstances. Adams [39] and Ogunpaimo, et al. [81] shared a similar view on females tilting towards the adoption of occupation diversification compared to the males.

Marital status: Table 3 showed that married farmers have the likelihood to use adaptation strategies such as irrigation facilities, crop diversification, and nonfarm diversification compared to singles. This is likely because more efforts come into making decisions when being married compared to being single. On the other hand, being married has a negative but significant influence on implementing soil conservation techniques. 
Years of schooling: From Table 3, it is shown that the years of schooling of the farm household head have mixed effects on the choice of CCA. This variable significantly and positively affected practicing diversification into non-farm activities $(p<0.01)$; this result shown in Table 3 supported the work of Ali and Erenstein [25], Alam [48], Gebrehiwot and Van Der Veen [49], and Alam, Alam and Mushtaq [60]. The papers all agreed that educated farmers may be more aware and perceive climate change, as they can easily understand and interpret information compared to farmers with a lower level of education. However, this philosophy did not work for the adoption of some strategies; years of schooling negatively influenced the probability of practicing soil conservation $(p<0.01)$ and crop diversification $(p<0.01)$.

Quantity of Household Asset: The quantity of household assets, which is a proxy of the wealth status of farming households, is an important variable that reflects farmers' choice of climate change adaptation options. Results shown in Table 3 contradict Ali and Erenstein [25] in that quantity of household assets enacted a negative influence on climate change adaptation options except for non-farm diversification $(p<0.01)$. It can be implied that income from the use and sale of household size is diverted mainly into non-farm diversification with non-farm diversification serving as secondary income to the farming households.

Location: Location typically plays an important role in CCA adoption [25,82-85]. In this study, we included dummies for agroecological zones to control for the location effect on adaptation strategies, with South-South being the base for the model. The result indicated a significant positive and significant probability of farm households in NorthCentral and North-West to implement irrigation facilities compared to farm households in the South-South region. The likelihood of adopting soil conservation techniques increases with residing in all other regions of the country in relation to the South-South zone. The findings in Table 3 also highlighted that all the zones, except for the South-West zone, negatively affect the probability of farming households to diversify into non-farm activities concerning those in the South-South region.

\subsection{Impact of Climate Change Adaptation on Household Food Security}

A combination of PSM and DID was used to evaluate the impact of CCA adoption on household food security. It is therefore imperative to discuss the result of the impact of CCA options on household food security between adopters and non-adopters from 2010 to 2016.

\subsubsection{PSM Result of Impact of CCA on Household Food Security}

The with and without effect of climate change adaptation options is explained by PSM. Table 4 presents the impacts of adaptation methods used on household food security based on propensity score matching. The impact of climate change adaptation on household food security was significant with adopters having $9 \%$ higher food security than non-adopters in 2010. This result is in support of Ali and Erenstein [25], but against Weldegebriel and Prowse [86] who found that the adaptation strategy reduced farm income and, with that, food security due to the exclusion of important variables. Ali and Erenstein [25] stated that CCA practices help to enhance the food security and welfare of rural households. Thus, farm households should be encouraged to adopt a few CCA practices to improve welfare outcomes. Farm households not adopting CCA practices are more likely to be food insecure. Shiferaw, et al. [87] also opined that the average treatment effect on the treated (ATT) of adaptation on household food security was positive and significant, which implied that CCA options foster household food security. 
Table 4. PSM Showing the Impact of CCA Adoption on Household Food Security.

\begin{tabular}{cccccc}
\hline Outcome Variable & ATT & t-Values & Mean Bias & Median Bias & Bias Reduction \\
\hline Food security & $0.09 * *$ & 2.15 & 4.2 & 4.3 & $83 \%$ \\
\hline Authors computation of LSMS data $2010-2016 .{ }^{* *}$ represents statistical significance at $5 \%$ respectively.
\end{tabular}

Table 5 shows the covariate balancing tests before and after matching. As indicated in the table, the balancing test revealed that the bias was relatively higher before matching.

Table 5. Covariate Balancing test for the difference between CCA Adopters and non-adopters.

\begin{tabular}{|c|c|c|c|c|c|}
\hline Variable & $\begin{array}{l}\text { Before Matching- } \\
\text { Mean Absolute Bias }\end{array}$ & $\begin{array}{c}\text { After Matching } \\
\text { Mean Absolute } \\
\text { Bias }\end{array}$ & $\begin{array}{c}\text { t-Vals of } \\
\text { Covariates before } \\
\text { Matching }\end{array}$ & $\begin{array}{c}\text { t-Vals of } \\
\text { Covariates After } \\
\text { Matching }\end{array}$ & $\begin{array}{c}\% \text { Reduction } \\
\text { Bias }\end{array}$ \\
\hline Credit & 0.001 & 0.01 & 0.15 & 1.63 & 75.8 \\
\hline Tenancy Status & 0.06 & 0.01 & 1.90 & 1.13 & 74.7 \\
\hline Farm size & 0.07 & 0.01 & 0.11 & 1.44 & 70.4 \\
\hline Extension contact & 0.06 & 0.002 & 2.82 & 0.13 & 97.2 \\
\hline Age of $\mathrm{HH}$ & 1.62 & 0.28 & 1.49 & 0.41 & 82.6 \\
\hline Gender of HH & 0.07 & 0.002 & 3.94 & 1.39 & 97.2 \\
\hline Years of Schooling & 0.49 & 0.09 & 2.07 & 0.25 & 82 \\
\hline Marital Status & 0.03 & 0.01 & 1.19 & 0.69 & 65 \\
\hline HH SIZE & 0.08 & 0.01 & 0.41 & 1.33 & 88.7 \\
\hline HH ASSET & 0.516 & 0.112 & 0.87 & 0.41 & 78.1 \\
\hline
\end{tabular}

Authors computation of LSMS data 2010-2016.

For instance, before matching tenancy status $(p<0.10)$, extension contact $(p<0.05)$ and gender of the household head $(p<0.01)$ could cause selection bias when assessing the influence of CCA options on household food security status. The percentage bias reduction is between 65-97.2\%. These indicators of covariates balancing showed the results obtained satisfied the balancing of covariates following matching and the application of the common support condition. The result implied no selection bias when matching adopters and non-adopters, thus differences in food security levels are mainly due to the adoption of CCA measures.

\subsubsection{DID Result of Impact of CCA on Household Food Security}

The true impact of CCA on household food security over time can be measured by looking at the effects of adaptation options between adopters and non-adopters, which was illustrated by the result of the PSM and then measuring the impact of the adaptation measures over the period of adoption using the DID. The adopter and the non-adopter groups within the same common support in the PSM analysis for the base period were appended, after which the DID analysis was carried out.

The difference in difference (DID) estimation combined with propensity score matching (PSM) was used to evaluate the average impact of the CCA options on household food security. The average treatment effects of CCA options were evaluated, which compares food security in the adoption state $\left(\mathrm{Y}_{1}\right)$ with the outcomes in the control or the counterfactual $\left(\mathrm{Y}_{0}\right)$ conditional on receiving treatment.

Contrary to previous studies $[25,88]$, which used cross-sectional data to assess the impact of CCA options, this study used panel data for six time periods to assess the impact of CCA options on household food security. Similar to Kangmennaang et al. [26] and Kabunga, et al. [89], this approach allowed for the combination of propensity score matching with DID estimation to control for selection bias and temporal impact variability. The estimated results showed that adopting CCA options intervention positively influenced household food security.

As shown in Table 6 , the F-value is significant at $(p<0.01)$, which indicated that the model was useful in assessing the impact of CCA on household food security over 
time. The result in Table 6 showed that the coefficient of time trend (y16) was significant ( $\beta=-4.02, p<0.01)$; this implied that household food security was trending down with time. The result of the DID is positive and significant $(\beta=5.93, p<0.01)$, which reveals that the impact of the CCA options increases household food security between adopters and non-adopters. This finding confirms that CCA options had a significant positive impact on farm households' food security status. This finding shared similar results with Noltze, et al. [90], and Kangmennaang et al. [26] who found that agroecological practices in the form of CCA promote food security after 2 years. However, while this study adopted the use of HFES as a measure of food security, Kangmennaang et al. [26] used the Household Food Insecurity Access Scale (HFIAS).

Table 6. DID Showing the Impact of CCA Options on Household Food Security Without Covariates.

\begin{tabular}{cccc}
\hline $\begin{array}{c}\text { Household Food } \\
\text { Expenditure }\end{array}$ & Coefficient & $\begin{array}{c}\text { Robust Standard } \\
\text { Error }\end{array}$ & t-Values \\
\hline Adapt & $4.86^{* * *}$ & 1.09 & 4.45 \\
y16 & $-4.02^{* * *}$ & 0.50 & -8.06 \\
DID & $5.93^{* * *}$ & 0.68 & 8.73 \\
Constant & 76.00 & 0.91 & 83.29 \\
\hline F-value & $\mathbf{3 3 . 8 5 * * *}{ }^{* * *}$ & & \\
Prob > F & $\mathbf{0 . 0 0 0}$ & & \\
\hline Authors computation of LSMS data $2010-2016$ $^{* * *}$ represent statistical significance at 1\% respectively.
\end{tabular}

It must be noted that CCA adoption may be implemented by farming households before the year 2010, however, 2010 was used as the baseline due to data availability. The findings in this study also support the result of other studies that confirmed the direct effects of CCA options on household food security. Becerril and Abdulai [91] reported that increased farm output can lead to higher consumption, off-farm diversification, and increased farm incomes. Surpluses from farm yield may also be used to increase the household quantity of assets increasing the adaptive capacity of households to climate change, thus promoting households' food security status [92,93]. Khonje, et al. [94] also reported that sustainable practices such as crop diversification and other CCA options can lead to improved welfare and food security outcomes. Other effects of adopting CCA options reported may include promoting women empowerment, capacity-building, and knowledge exchange within the community, which may further lead to increased food production at the community level, increased consumption, and better living standard conditions [26]. Adopting CCA options can also foster collective relationships among farming households within the communities, allowing for the sharing of risks and burdens associated with farm activities.

To control for any selection bias between the adopters and non-adopters of CCA, the results obtained in Table 6 were controlled for covariates influences on the impact of CCA on household food security status, as shown in Table 7 . The result obtained indicated that even after controlling for potential covariate influence, DID had a positive and significant ( $\beta=4.15, p<0.01$ ) effect on household food security status. This result was corroborated by [26] who found that covariates control does not influence the outcome of the DID result or the influence of CCA on the household food security status. 
Table 7. DID Showing the Impact of Adaptation Options on Household Food Security with Covariates.

\begin{tabular}{cccc}
\hline $\begin{array}{c}\text { Food Security } \\
\text { Outcome }\end{array}$ & Coefficient & $\begin{array}{c}\text { Robust Standard } \\
\text { Error }\end{array}$ & t-Values \\
\hline Adapt & $4.34^{* * *}$ & 1.22 & 3.55 \\
Time & -3.13 & 3.17 & -0.99 \\
DID & $4.15^{* * *}$ & 1.01 & 4.11 \\
Constant & 79.90 & 2.90 & 36.36 \\
\hline F-value & $\mathbf{1 3 . 5 5 ^ { * * * }}$ & & \\
Prob $>$ F & $\mathbf{0 . 0 0 0}$ & & \\
\hline Authors computation of LSMS data $2010-2016 .^{* * *}$ represent statistical significance at 1\% respectively.
\end{tabular}

\section{Conclusions}

This study assessed the impact of climate change adaptation (CCA) on household food security among farm households in Nigeria. Against previous works of literature that adopted cross-sectional approaches to investigate CCA impacts on welfare outcomes, this research work adopted a panel data analysis, thus measuring the impacts of CCA on household food security across space and time. We recognized that there are other CCA options not considered in this study mainly due to lack or limited data of such CCA strategies in the LSMS data. However, this study has provided useful insights and information on the relationship between CCA options and household food security in Nigeria. Based on the aforementioned findings, this study confirmed the need for adaptation to climate change by farming households, which increase with an increase in farm size, extension contact, and marital status, with access to credit, ownership of farmland, household size, the gender of household size, years of schooling, household asset and location having mixed effects on the choice of adaptation strategies. From the study, it was shown that climate change adaptations have helped farming households improve their food security status in the face of prevalent climatic conditions. Therefore, the study recommends that farming households should practice continual implementation of CCA options to foster improvement in household food security status. Also, access to credit facilities and extension contacts remains a catalyst for implementing adaptation measures, thus constant and quality extension contacts and credit facilities with low-interest rates should be provided to farming households to enable them to adapt better to climate changes and improve household food security status.

Author Contributions: Conceptualization, O.R.O.; Formal analysis, O.R.O.; Methodology, O.R.O.; Software, O.R.O.; Validation, Z.O.-U., and J.S.; Writing-original draft, O.R.O.; Writing-review \& editing, Z.O.-U., and J.S. All authors have read and agreed to the published version of the manuscript.

Funding: This research received no external funding.

Institutional Review Board Statement: Not applicable.

Informed Consent Statement: Not applicable.

Data Availability Statement: Publicly available datasets were analyzed in this study. This data can be found here: [https://microdata.worldbank.org/index.php/catlog/lsms/] at reference number [Ref: NGA_2010_GHSP-W1_v03_M, Ref: NGA_2012_GHSP-W2_v02_M, Ref: NGA_2015_GHSPW3_v02_M].

Conflicts of Interest: No conflict of interest was declared by the authors of this paper.

\section{References}

1. Medugu, I.N.; Majid, M.R.; Choji, I. A comprehensive approach to drought and desertification in Nigeria. Manag. Environ. Qual. Int. J. 2008. [CrossRef]

2. Abaje, I.; Ati, O.; Iguisi, E.; Jidauna, G. Droughts in the sudano-sahelian ecological zone of Nigeria: Implications for agriculture and water resources development. Glob. J. Hum. Soc. Sci. B Geogr. Geo Sci. Environ. 2013, 13, 1-10.

3. Echendu, A.J. The impact of flooding on Nigeria's sustainable development goals (SDGs). Ecosyst. Health Sustain. 2020, 6, 1791735. [CrossRef] 
4. Teklewold, H.; Kassie, M.; Shiferaw, B. Adoption of multiple sustainable agricultural practices in rural Ethiopia. J. Agric. Econ. 2013, 64, 597-623. [CrossRef]

5. El-ladan, I. Climate change and food security in Nigeria. In Proceedings of the International Conference on Possible Impacts of Climate Change on Africa, Institute of African Research and Studies, Cairo University, Cairo, Egypt, 18-20 May $2014 ;$ p. 16.

6. Firdaus, R.R.; Gunaratne, M.S.; Rahmat, S.R.; Kamsi, N.S. Does climate change only affect food availability? What else matters? Cogent Food Agric. 2019, 5, 1707607. [CrossRef]

7. FAO; IFAD; UNICEF; WFP; WHO. The State of Food Security and Nutrition in the World 2018: Building Climate Resilience for Food Security and Nutrition; Food \& Agriculture Organization: Rome, Italy, 2018.

8. Edame, G.E.; Ekpenyong, A.; Fonta, W.M.; Duru, E. Climate change, food security and agricultural productivity in Africa: Issues and policy directions. Int. J. Humanit. Soc. Sci. 2011, 1, 205-223.

9. FAO. Climate Change and Food Security: A Framework Document; Food and Agriculture Organization of the United Nations: Rome, Italy, 2008.

10. von Grebmer, K.; Bernstein, J.; Alders, R.; Dar, O.; Kock, R.; Rampa, F.; Wiemers, M.; Acheampong, K.; Hanano, A.; Higgins, B.; et al. 2020 Global Hunger Index: One Decade to Zero Hunger: Linking Health and Sustainable Food Systems; Welthungerhilfe: Bonn, Germany; Concern Worldwide: Dublin, Iraland, 2020.

11. Adebayo, O.; Olagunju, K.; Kabir, S.K.; Adeyemi, O. Social crisis, terrorism and food poverty dynamics: Evidence from Northern Nigeria. Int. J. Econ. Financ. Issues 2016, 6. [CrossRef]

12. Korir, L.; Rizov, M.; Ruto, E. Analysis of Household Food Demand and Its Implications on Food Security in Kenya: An Application of QUAIDS Model. In Proceedings of the Agricultural Economics Society, 92nd Annual Conference 2018, Coventry, UK, 16-18 April 2018.

13. Ikudayisi, A.; Okoruwa, V.; Omonona, B. From the lens of food accessibility and dietary quality: Gaining insights from urban food security in Nigeria. Outlook Agric. 2019, 48, 336-343. [CrossRef]

14. Adeniyi, D.A.; Dinbabo, M.F. Factors Influencing Household Food Security Among Irrigation Smallholders in North West Nigeria. J. Rev. Glob. Econ. 2019, 8, 291-304. [CrossRef]

15. The Sustainable Development Goals Report 2018; UN General Assembly: New York, NY, USA, 2018; p. 36.

16. Chambwera, M.; Zou, Y.; Boughlala, M. Better Economics: Supporting Adaptation with Stakeholder Analysis; International Institute for Environment and Development (IIED): London, UK, 2011.

17. FAO. Climate Change, Agriculture and Food Security. Available online: https://reliefweb.int/sites/reliefweb.int/files/resources/ a-i6030e.pdf (accessed on 18 September 2020).

18. FAO; IFAD; UNICEF; WFP; WHO. The state of food security and nutrition in the world 2017. In Building Resilience for Peace and Food Security; FAO: Rome, Italy, 2017.

19. Field, C.B. Climate Change 2014-Impacts, Adaptation and Vulnerability: Regional Aspects; Cambridge University Press: Cambridge, UK, 2014.

20. Steynor, A.; Pasquini, L. Informing climate services in Africa through climate change risk perceptions. Clim. Serv. 2019, 15, 100112. [CrossRef]

21. Field, C.B.; Barros, V.R.; Mastrandrea, M.D.; Mach, K.J.; Abdrabo, M.-K.; Adger, N.; Anokhin, Y.A.; Anisimov, O.A.; Arent, D.J.; Barnett, J. Summary for policymakers. In Climate Change 2014: Impacts, Adaptation, and Vulnerability. Part A: Global and Sectoral Aspects. Contribution of Working Group II to the Fifth Assessment Report of the Intergovernmental Panel on Climate Change; Cambridge University Press: Cambridge, UK, 2014; pp. 1-32.

22. Ebele, N.E.; Emodi, N.V. Climate change and its impact in Nigerian economy. J. Sci. Res. Rep. 2016, 1-13. [CrossRef] [PubMed]

23. Abdulkadir, T.; Salami, A.; Aremu, A.; Ayanshola, A.; Oyejobi, D. Assessment of neural networks performance in modeling rainfall amounts. J. Res. For. Wildl. Environ. 2017, 9, 12-22.

24. Elum, Z.A.; Modise, D.M.; Marr, A. Farmer's perception of climate change and responsive strategies in three selected provinces of South Africa. Clim. Risk Manag. 2017, 16, 246-257. [CrossRef]

25. Ali, A.; Erenstein, O. Assessing farmer use of climate change adaptation practices and impacts on food security and poverty in Pakistan. Clim. Risk Manag. 2017, 16, 183-194. [CrossRef]

26. Kangmennaang, J.; Kerr, R.B.; Lupafya, E.; Dakishoni, L.; Katundu, M.; Luginaah, I. Impact of a participatory agroecological development project on household wealth and food security in Malawi. Food Secur. 2017, 9, 561-576. [CrossRef]

27. Morland, A. Climate Change, Food Security and Adaptation. Available online: https://www.thenewhumanitarian.org/analysis/ 2017/06/14/fact-file-climate-change-food-security-and-adaptation (accessed on 21 September 2020).

28. European Commission. Adaptation to Climate Change. Available online: https://ec.europa.eu/clima/policies/adaptation_en (accessed on 18 September 2020).

29. Ade Ajayi, J.F.; Kirk-Greene, A.H.M.; Udo, R.K.; Falola, T.O. Nigeria. Available online: https://www.britannica.com/place/ Nigeria (accessed on 15 December 2020).

30. National Bureau of Statistics, Federal Republic of Nigeria. Nigeria General Household Survey (GHS), Panel 2010, Wave 1 Ref. NGA_2010_GHSP-W1_v03_M; National Bureau of Statistics: Abuja, Nigeria, 2010.

31. National Bureau of Statistics, Federal Republic of Nigeria. Nigeria General Household Survey, Panel 2012-2013, Wave 2. Ref. NGA_2012_GHSP-W2_v02_M; National Bureau of Statistics: Abuja, Nigeria, 2012. 
32. National Bureau of Statistics, Federal Republic of Nigeria. General Household Survey, Panel (GHS-Panel) 2015-2016.Ref. NGA_2015_GHSP-W3_v02_M; National Bureau of Statistics: Abuja, Nigeria, 2015.

33. Ogunpaimo, O.R.; Dipeolu, A.O.; Ogunpaimo, O.J.; Akinbode, S.O. Determinants of choice of climate change adaptation options among cassava farmers, in southwest Nigeria. Futo J. Ser. 2020, 6, 25-39.

34. GADM. Country Profile. Available online: https://gadm.org/download_country_v3.html (accessed on 25 January 2021).

35. Birungi, P.B. The Linkages between Land Degradation, Poverty and Social Capital in Uganda; University of Pretoria: Pretoria, South Africa, 2008.

36. Mugi-Ngenga, E.; Mucheru-Muna, M.; Mugwe, J.; Ngetich, F.; Mairura, F.; Mugendi, D. Household's socio-economic factors influencing the level of adaptation to climate variability in the dry zones of Eastern Kenya. J. Rural Stud. 2016, 43, 49-60. [CrossRef]

37. Dolisca, F.; Carter, D.R.; McDaniel, J.M.; Shannon, D.A.; Jolly, C.M. Factors influencing farmers' participation in forestry management programs: A case study from Haiti. For. Ecol. Manag. 2006, 236, 324-331. [CrossRef]

38. Tizale, C.Y. The Dynamics of Soil Degradation and Incentives for Optimal Management in the Central Highlands of Ethiopia; University of Pretoria: Pretoria, South Africa, 2007.

39. Adams, O.R. Climate Variability and Adaptation Strategies in Cassava Production in Ogun State, Nigeria; Federal University of Agriculture: Abeokuta, Nigeria, 2015.

40. Ijaiya, M.; Abdulraheem, A.; Abdullahi, I. Agricultural credit guarantee scheme and food security in Nigeria. Ethiop. J. Environ. Stud. Manag. 2017, 10, 208-218. [CrossRef]

41. Aku, P. Comparative analysis of NACB and ACGSF Loan disbursement to agriculture in Nigeria. J. Soc. Manag. Stud. 1995, 2, 99-108.

42. Smith, L.C.; Subandoro, A. Measuring Food Security Using Household Expenditure Surveys; Food Security in Practice Technical Guide Series; International Food Policy Research Institute: Washington, DC, USA, 2007; p. 146.

43. Akerele, D.; Sanusi, R.; Fadare, O.; Ashaolu, O. Factors influencing nutritional adequacy among rural households in Nigeria: How does dietary diversity stand among influencers? Ecol. Food Nutr. 2017, 56, 187-203. [CrossRef] [PubMed]

44. Cameron, A.C.; Trivedi, P.K. Microeconometrics Using Stata; Stata Press College Station: College Station, TX, USA, 2009 ; Volume 5.

45. Deressa, T.T.; Hassan, R.M.; Ringler, C. Perception of and adaptation to climate change by farmers in the Nile basin of Ethiopia. J. Agric. Sci. 2011, 149, 23-31. [CrossRef]

46. Oyetunde-Usman, Z.; Olagunju, K.O.; Ogunpaimo, O.R. Determinants of adoption of multiple sustainable agricultural practices among smallholder farmers in Nigeria. Int. Soil Water Conserv. Res. 2020. [CrossRef]

47. Temesgen, D.; Hassan, R.; Tekie, A.; Mahmud, Y.; Ringler, C. Analyzing the Determinants of Farmers' Choice of Adaptation Methods and Perceptions of Climate Change in the Nile Basin of Ethiopia; International Food Policy Research Institute (IFPRI): Washington, DC, USA, 2008.

48. Alam, K. Farmers' adaptation to water scarcity in drought-prone environments: A case study of Rajshahi District, Bangladesh. Agric. Water Manag. 2015, 148, 196-206. [CrossRef]

49. Gebrehiwot, T.; Van Der Veen, A. Farm level adaptation to climate change: The case of farmer's in the Ethiopian Highlands. Environ. Manag. 2013, 52, 29-44. [CrossRef]

50. Vo, H.H.; Mizunoya, T.; Nguyen, C.D. Determinants of farmers' adaptation decisions to climate change in the central coastal region of Vietnam. Asia Pac. J. Reg. Sci. 2021, 1-23. [CrossRef]

51. Tambo, J.A. Adaptation and resilience to climate change and variability in north-east Ghana. Int. J. Disaster Risk Reduct. 2016, 17, 85-94. [CrossRef]

52. Mekuyie, M.; Mulu, D. Perception of impacts of climate variability on pastoralists and their adaptation/coping strategies in fentale district of Oromia Region, Ethiopia. Environ. Syst. Res. 2021, 10, 1-10. [CrossRef]

53. Rosenbaum, P.R.; Rubin, D.B. The central role of the propensity score in observational studies for causal effects. Biometrika 1983, 70, 41-55. [CrossRef]

54. Dehejia, R.H.; Wahba, S. Propensity score-matching methods for nonexperimental causal studies. Rev. Econ. Stat. 2002, 84, 151-161. [CrossRef]

55. Smith, L.C.; Dupriez, O.; Troubat, N. Assessment of the Reliability and Relevance of the Food Data Collected in National Household Consumption and Expenditure Surveys; International Household Survey Network: Oxford, UK, 2014; p. 69.

56. Khandker, S.B.; Koolwal, G.; Samad, H. Handbook on Impact Evaluation: Quantitative Methods and Practices; The World Bank: Washington, DC, USA, 2009. [CrossRef]

57. Becker, S.O.; Ichino, A. Estimation of average treatment effects based on propensity scores. Stata J. 2002, 2, 358-377. [CrossRef]

58. Caliendo, M.; Kopeinig, S. Some practical guidance for the implementation of propensity score matching. J. Econ. Surv. 2008, 22, 31-72. [CrossRef]

59. Hisali, E.; Birungi, P.; Buyinza, F. Adaptation to climate change in Uganda: Evidence from micro level data. Glob. Environ. Chang. 2011, 21, 1245-1261. [CrossRef]

60. Alam, G.M.; Alam, K.; Mushtaq, S. Influence of institutional access and social capital on adaptation decision: Empirical evidence from hazard-prone rural households in Bangladesh. Ecol. Econ. 2016, 130, 243-251. [CrossRef]

61. Boansi, D.; Tambo, J.A.; Müller, M. Analysis of farmers' adaptation to weather extremes in West African Sudan Savanna. Weather Clim. Extrem. 2017, 16, 1-13. [CrossRef] 
62. Hassan, R.M.; Nhemachena, C. Determinants of African farmers' strategies for adapting to climate change: Multinomial choice analysis. Afr. J. Agric. Resour. Econ. 2008, 2, 83-104. [CrossRef]

63. Ojo, T.; Baiyegunhi, L. Determinants of credit constraints and its impact on the adoption of climate change adaptation strategies among rice farmers in South-West Nigeria. J. Econ. Struct. 2020, 9, 1-15. [CrossRef]

64. Arunrat, N.; Wang, C.; Pumijumnong, N.; Sereenonchai, S.; Cai, W. Farmers' intention and decision to adapt to climate change: A case study in the Yom and Nan basins, Phichit province of Thailand. J. Clean. Prod. 2017, 143, 672-685. [CrossRef]

65. Quan, J. Land Access in the Early 21st Century: Issues, Trends, Linkages and Policy Options; FAO Livelihoods Support Programme Working Paper 24; FAO: Rome, Italy, 2006.

66. Kokoye, S.E.H.; Yabi, J.A.; Tovignan, S.D.; Yegbemey, R.N.; Nuppenau, E.-A. Simultaneous modelling of the determinants of the partial inputs productivity in the municipality of Banikoara, Northern Benin. Agric. Syst. 2013, 122, 53-59. [CrossRef]

67. Fosu-Mensah, B.Y.; Vlek, P.L.; MacCarthy, D.S. Farmers' perception and adaptation to climate change: A case study of Sekyedumase district in Ghana. Environ. Dev. Sustain. 2012, 14, 495-505. [CrossRef]

68. Iheke, O.R.; Agodike, W.C. Analysis of factors influencing the adoption of climate change mitigating measures by smallholder farmers in IMO state, Nigeria. Sci. Pap. Ser. Manag. Econ. Eng. Agric. Rural. Dev. 2016, 16, 213-220.

69. Nabikolo, D.; Bashaasha, B.; Mangheni, M.; Majaliwa, J. Determinants of climate change adaptation among male and female headed farm households in eastern Uganda. Afr. Crop Sci. J. 2012, 20, 203-212.

70. Abid, M.; Scheffran, J.; Schneider, U.A.; Ashfaq, M. Farmers' perceptions of and adaptation strategies to climate change and their determinants: The case of Punjab province, Pakistan. Earth Syst. Dyn. 2015, 6, 225-243. [CrossRef]

71. Abid, M.; Schneider, U.A.; Scheffran, J. Adaptation to climate change and its impacts on food productivity and crop income: Perspectives of farmers in rural Pakistan. J. Rural Stud. 2016, 47, 254-266. [CrossRef]

72. Iqbal, M.; Ahmad, M.; Mustafa, G. Impact of Farm Households' Adaptation on Agricultural Productivity: Evidence from Different Agro-Ecologies of Pakistan. Clim. Chang. Work. Pap. 2015, 5, 17.

73. Javed, S.; Kishwar, S.; Iqbal, M. From Perceptions to Adaptation to Climate Change: Farm Level Evidence from Pakistan; Pakistan Institute of Development Economics: Islamabad, Pakistan, 2015.

74. Tiwari, V.; Wahr, J.; Swenson, S. Dwindling groundwater resources in northern India, from satellite gravity observations. Geophys. Res. Lett. 2009, 36. [CrossRef]

75. Bryan, E.; Ringler, C.; Okoba, B.; Roncoli, C.; Silvestri, S.; Herrero, M. Adapting agriculture to climate change in Kenya: Household strategies and determinants. J. Environ. Manag. 2013, 114, 26-35. [CrossRef]

76. Gbetibouo, G.A. Understanding Farmers Perceptions and Adaptations to Climate Change and Variability: The Case of the Limpopo Basin Farmers South Africa; IFPRI Research Brief: Washington, DC, USA, 2009.

77. Arshad, M.; Amjath-Babu, T.; Kächele, H.; Müller, K. What drives the willingness to pay for crop insurance against extreme weather events (flood and drought) in Pakistan? A hypothetical market approach. Clim. Dev. 2016, 8, 234-244. [CrossRef]

78. Le Dang, H.; Li, E.; Nuberg, I.; Bruwer, J. Farmers' assessments of private adaptive measures to climate change and influential factors: A study in the Mekong Delta, Vietnam. Nat. Hazards 2014, 71, 385-401. [CrossRef]

79. Trinh, T.Q.; Rañola, R.F., Jr.; Camacho, L.D.; Simelton, E. Determinants of farmers' adaptation to climate change in agricultural production in the central region of Vietnam. Land Use Policy 2018, 70, 224-231. [CrossRef]

80. Asrat, P.; Simane, B. Farmers' perception of climate change and adaptation strategies in the Dabus watershed, North-West Ethiopia. Ecol. Process. 2018, 7, 7. [CrossRef]

81. Ogunpaimo, O.R.; Ogbe, A.; Edewor, S. Determinants of factors affecting adaptation strategies to climate change in cassava processing in South West, Nigeria. In Proceedings of the 6th African Conference of Agricultural Economists, Abuja, Nigeria, 23-25 September 2019; p. 17.

82. Vincent, K. Uncertainty in adaptive capacity and the importance of scale. Glob. Environ. Chang. 2007, 17, 12-24. [CrossRef]

83. Tiwari, K.R.; Sitaula, B.K.; Nyborg, I.L.; Paudel, G.S. Determinants of farmers' adoption of improved soil conservation technology in a middle mountain watershed of central Nepal. Environ. Manag. 2008, 42, 210-222. [CrossRef] [PubMed]

84. Hinkel, J. "Indicators of vulnerability and adaptive capacity": Towards a clarification of the science-policy interface. Glob. Environ. Chang. 2011, 21, 198-208. [CrossRef]

85. Below, T.B.; Mutabazi, K.D.; Kirschke, D.; Franke, C.; Sieber, S.; Siebert, R.; Tscherning, K. Can farmers' adaptation to climate change be explained by socio-economic household-level variables? Glob. Environ. Chang. 2012, 22, 223-235. [CrossRef]

86. Weldegebriel, Z.B.; Prowse, M. Climate-change adaptation in Ethiopia: To what extent does social protection influence livelihood diversification? Dev. Policy Rev. 2013, 31, 35-56. [CrossRef]

87. Shiferaw, B.; Kassie, M.; Jaleta, M.; Yirga, C. Adoption of improved wheat varieties and impacts on household food security in Ethiopia. Food Policy 2014, 44, 272-284. [CrossRef]

88. Ogunniyi, A.; Omonona, B.; Abioye, O.; Olagunju, K. Impact of irrigation technology use on crop yield, crop income and household food security in Nigeria: A treatment effect approach. AIMS Agric. Food 2018, 3, 154-171. [CrossRef]

89. Kabunga, N.S.; Dubois, T.; Qaim, M. Impact of tissue culture banana technology on farm household income and food security in Kenya. Food Policy 2014, 45, 25-34. [CrossRef]

90. Noltze, M.; Schwarze, S.; Qaim, M. Impacts of natural resource management technologies on agricultural yield and household income: The system of rice intensification in Timor Leste. Ecol. Econ. 2013, 85, 59-68. [CrossRef] 
91. Becerril, J.; Abdulai, A. The impact of improved maize varieties on poverty in Mexico: A propensity score-matching approach. World Dev. 2010, 38, 1024-1035. [CrossRef]

92. Wanjala, B.M.; Muradian, R. Can big push interventions take small-scale farmers out of poverty? Insights from the Sauri Millennium Village in Kenya. World Dev. 2013, 45, 147-160. [CrossRef]

93. Orr, A.; Mausch, K. How Can We Make Smallholder Agriculture in the Semi-Arid Tropics More Profitable and Resilient? Working Paper Series No. 59; International Crops Research Institute for Semi-Arid Tropics: Nairobi, Kenya, 2014; p. 28.

94. Khonje, M.; Manda, J.; Alene, A.D.; Kassie, M. Analysis of adoption and impacts of improved maize varieties in eastern Zambia. World Dev. 2015, 66, 695-706. [CrossRef] 